\title{
De las semánticas modernas de pueblo a sus modulaciones sociológicas reactivas
}

From the modern semantics of the people to their reactive sociological modulations

\section{ÁNGEL ENRIQUE CARRETERO PASÍN*}

Debussy planteaba perfectamente el problema de lo Uno-Muchedumbre cuando le reprochaba a Wagner que no supiera "hacer" una muchedumbre o un pueblo: una muchedumbre debe estar plenamente individuada, pero por individuaciones de grupo, que no se reducen a la individualidad de los sujetos que la componen. El pueblo debe individuarse, no según las personas, sino según los afectos que simultánea y sucesivamente experimenta.

Deleuze y Guattari (1994)

Resumen: Partiendo de las directrices teóricas proporcionadas por la historia conceptual de Koselleck y apoyándonos, paralelamente, en la noción de imaginario social de Castoriadis nos detenemos en el examen de la categoría de pueblo. Aclaramos la genealogía y desarrollo de esta categoría hasta su cristalización, en sus diferentes perfiles, en la modernidad. La relevancia de la noción impulsada por Castoriadis consiste en que solo mediante la institucionalización de un imaginario social de pueblo, un magma in-determinado pasará a ser estructurado bajo el umbral epistémico de una determinación como pueblo. La hipótesis analítica que aquí se sugiere incide en el desgaste de la frescura de los relatos sobre el pueblo que, forjados desde ciertos imaginarios sociales, habían sido construidos en el curso de la modernidad para dar una conformación sustantiva a la in-determinación de pueblo. Y como, a consecuencia de lo anterior, se estaría anunciando el despunte de unas manifestaciones sociológicas indiferentes a las categorizaciones de pueblo modernas. Con el término metafórico masa aludimos a una común inclinación de estas manifestaciones, examinando de cerca algunas de sus expresiones más paradigmáticas.

Palabras clave: Imaginario social, pueblo, identidades, multitud, populismo.

Abstract: Starting from the theoretical guidelines provided by the conceptual history of Koselleck and supporting us, parallel, in the notion of social imaginary of Castoriadis we stop at the examination of the category of people. We clarify the genealogy and development

\footnotetext{
* Profesor Asociado, Departamento de Antropología, Universidad de Santiago de Compostela, Santiago de Compostela, España. Miembro de la Red Iberoamericana de Investigación en imaginarios y Representaciones. Código ORCID: org/0000-0002-2498-1291 Contacto: angelenrique.carretero@usc.es
} 
of this category until its crystallization, in its different profiles, in modernity. The relevance of the notion promoted by Castoriadis is that only through the institutionalization of a social imaginary of the people, an in-determined something will be structured under an epistemic threshold: the determination as a people. The analytical hypothesis suggested here affects the erosion of the freshness of the stories about the people that, forged from certain social imaginaries, had been constructed in the course of modernity to give a substantive conformation to the in-determination of the people. And as a result of the above, it would be announcing the breakthrough of sociological manifestations indifferent to the categorizations of modern people. With the term metaphorical mass we alluded to a common inclination of these manifestations, examining closely some of their most paradigmatic expressions.

Key words: social imaginary, people, identities, crowd, populism.

\title{
Introducción: una aproximación epistémica a la conceptualización de pueblo
}

\begin{abstract}
A través de la obra de Koselleck (1993, p. 106-127, 2003, p. 37-71), el enfoque proporcionado por la denominada historia conceptual ha ido ganando adeptos recientemente en las Ciencias Humanas y Sociales. Su objetivo medular ha sido el desgranar la arqueología y evolución de la semántica asociada a las categorías metapolíticas que habrían servido de hilo conductor en el léxico del pensamiento político occidental. Este enfoque koselleckiano lo complementaremos con un otro enfoque destilado de la noción de imaginario social -en lo sucesivo $I S$-, sugerida hace ya unas décadas por el filósofo y psicoanalista Castoriadis. Según este, básicamente, un magma social, propiamente indeterminado, reclama ser necesariamente estructurado bajo una determinación. ${ }^{1}$ Asumimos, entonces, un presupuesto ontológico en virtud del cual el ser último de lo real es "caos", "abismo sin fondo" (Castoriadis, 1994, p. 64). De manera que el denominador común a los múltiples modelos sociales haya sido una obstinación en negar esta ultimidad consustancial
\end{abstract}

\footnotetext{
1 Comentaba Adorno (1992, p. 151) el indecible esfuerzo que debió costar a la especie humana la implantación de una lógica de la identidad en la que se subsume un algo cualquiera y se parapeta su esencia. Lo que nos desvela que el magma social indistinto, in-determinado, inherente a un substrato extraño a todo sentido instituido, reclama ser objeto de estructuración bajo una forma identitaria determinada esculpida en una demarcación histórica. Reclamo que será colmado recurriendo, primero, a metáforas y, más tarde, a conceptos, mediante los cuales fijar una "verdad" en donde pueda ser encerrada, a riesgo de ser fosilizada, la ultimidad de un sentido de lo real que, pese a ello, persistirá en escaparse tozudamente de la vulnerabilidad de nuestro protésico cancelado (Nietzsche, 1994, p. 25). La in-determinación, originariamente esencial al mundo, da paso, así, a su completud en los márgenes de una determinación; eso sí, frágil y nunca enteramente inmunizada ante el inquietante asalto del sinsentido. Para el caso el armazón teórico puesto en liza por la Teoría de Sistemas luhmanniana resulta aleccionador. En este marco, la indeterminación, entendida en tanto complejidad de sentido en estado abierto e ilimitado, es por fuerza sometida a un autorreferencial procesamiento sistémico, reductor e inductor de una clausura de aquella. Así, la autopoiesis inherente al funcionamiento del sistema social operaría a través de la introducción de una contingente -que es, pero pudiera ser de otro modo- determinación limitadora de las infinitas posibilidades de sentido, transformando la incertidumbre en certidumbre (Luhmann, 1998, p. 77-99).
} 
al ser. ${ }^{2}$ Así, el IS designará la "articulación última”, el "esquema organizador", donador de un código de determinación para la inteligibilidad del sentido socialmente instituido (Castoriadis, 1983, p. 133). Esto quiere decir que el IS establece y cancela, en su globalidad, lo que es y debiera ser, cuáles son las cosas y qué son, lo que importa o vale y lo que no (Castoriadis, 1983, p. 135).

Con todo el interés más propiamente sociológico del $I S$ vendrá dado por lo que Castoriadis llama "significaciones segundas", con un carácter de abstracción más concreta, en una conexión interna y sobredeterminada por el IS central (Castoriadis, 1989, p. 314-320). Ahora bien, a fin de dar rigurosa cuenta de la actuación de las macroimaginarias "significaciones centrales" en la praxis cotidiana, se hace imprescindible escrutar la mediación entre las unas y las otras (Castro Nogueira, 1997, p. 41). En consecuencia, de la institucionalización de una "significación central", tal como es la de una imaginaria racionalización capitalista, se desprenderá y encarnará ipso facto un elenco de "instituciones segundas": familia, individuo, polis, mercancía o empresa, entre otras.

De entre ellas volcaremos aquí nuestro foco de atención en la instrumentación de la categoría, en gran medida transhistórica, de pueblo. Mediante la institucionalización de un tipo de $I S$, la insondable y magmática in-determinación del mero hecho de "estar juntos" se ve configurada y conminada en el umbral epistémico de una particular determinación como pueblo. Partimos de la idea de que pueblo «es lo indefinido, lo que no puede ser encerrado en definiciones ni ser capturado por conceptos» (Bergua, 2007, p. 26), y de que, por tanto, cualquier categorización que haya pretendido designar lo que tal instancia es, no ha consistido más que en yuxtaponer una arbitraria figuración y presentificación conferida a ésta sobre su in-determinación de fondo constitutiva.

De partida, recalcar que la categoría de pueblo ha estado teñida de raíz por la indefinición, y, aún más, por la ambivalencia. Por de pronto, el primer obstáculo para su delimitación genealógica ha comparecido con la incógnita de una mayor o menor coherencia en su traducción al singular o al plural. Popolo en italiano, Peuple en francés, Volk en alemán y Pueblo en español son vocablos empleados en singular, mientras People en inglés en plural. ${ }^{3}$ A mayores, la procedencia etimológica latina del término pone de manifiesto una

\footnotetext{
${ }^{2}$ Para ello se han afanado en instaurar una totalidad de relaciones de significatividad autointerpretativa del mundo, merced a la cual se establece lo que es digno de ser real o no serlo, de tener sentido o no tenerlo (Heidegger, 2000: 97-103). A decir verdad, el papel asignado históricamente al cuerpo de creencias religioso habría sido la gestión de la plausibilidad de esta significatividad. Con ello se habría logrado conferir un sentido fáctico en un sinsentido de fondo, fijar un umbral instituido de realidad -un nomos-, tenazmente defensor ante la amenaza de una acechante anomia que pudiera cernirse. A sabiendas, empero, de que la operatividad atesorada en este cuerpo de creencias radicaría en la opacidad del carácter arbitrariamente construido del sentido indiscutiblemente asumido (Berger, 1981, p. 193). De esta guisa, el sistema de interpretación del mundo asentado sobre un corpus de creencias religioso ha sido tradicionalmente la fórmula ideacional monopolizadora de una "significación central", de un $I S$, que, sin ser real ni racional, ha ejercido como instancia metonímica estructurante del sentido contenido en el entramado colectivo.

${ }^{3}$ Apoyándose en esta ambivalencia, Sartori (2007, p. 13-14) deshilvanará una taxonomía de tal categoría sostenida sobre seis factibles interpretaciones discordantes, sopesando la credibilidad de cada una de ellas. La problematización de esta diferente traducción no es caprichosa. La singularidad alude a una entidad única reflejada en una misma voluntad. La pluralidad lo hace a una agregación de una dispersa multiplicidad de voluntades.
} 
oscilación, ya embrionaria en su acepción, prolongada luego de manera crónica. Pueblo podría ser entonado como sinónimo simultáneamente de Populus -del conjunto de ciudadanos visto como sujeto soberano del cuerpo político- y de Plebs -del magma compuesto por los más desfavorecidos en la escala social y, por este motivo, privados del grado de soberanía política-. De esta suerte se hace preceptivo adoptar la diferenciación entre Pueblo y pueblo, en base a que una tal categoría esté prefigurada en virtud de un marco de definición político o no lo esté (Agamben, 1998, p. 225-229). En efecto, el término en cuestión fue incoado en Roma, más tarde es acoplado en el legado de la Cristiandad como Pueblo de Dios, y de ahí será asumido sin reservas por el Romanticismo, ya en el s. XIX, como Volk. Es decisivo que dicho término hubiera adquirido connotaciones discordantes en función de si es utilizado como parámetro representativo de la nación o, más bien, de los grupos subalternos; a resultas de lo cual quizá sea, a la postre, el término más metafísico -por vago y confuso- que pudiéramos encontrar (Bueno, 1997, p. 23).

\section{Prolegómenos a la configuración del $I S$ de pueblo: el trayecto hacia la modernidad}

Asumamos un axioma de partida: «El feudalismo es el resultado de la caída del Imperio romano, esto es, del fracaso del Estado» (Roca Barea, 2016, p. 347). Así, durante gran parte de la Edad Media y la época de transición en el Ancien Régime hasta la llegada de la modernidad, evaporada su primigenia semántica de raigambre romana, no cabe más que un bosquejo, aún pendiente de una contorneada figura, de un $I S$ de pueblo. En estas coordenadas, reparemos en el registro de una cultura académica oficializada, letrada en lengua latina y cuya elaboración era tarea transferida a las enclaustradas élites eclesiásticas. En paralelo a ella cohabitaba el registro de una cultura popular que, si bien capilarizada por la resonancia pedagógico-moral encerrada en las imágenes religiosas empleadas en las homilías sacerdotales, en ocasiones contrasta con la primera. No siendo inmune a ello, la captación del IS de pueblo se desdoblará de acuerdo con estos dos registros. Sabemos más del primero, dado que era escrito, que, del segundo, el cual era oral.

En relación a este segundo habría que apuntar que el semblante conceptual de la cultura popular, y no solo en su época de mayor brillo en sociedades antecedentes a la modernidad, es tan borroso como lo es el IS popular en torno al pueblo. ${ }^{4}$ Con todo sí se encuentra una pista aclaratoria de su idiosincrasia que no induce a engaño, a saber: aquel patrón de cultura no oficial, el de los grupos que no formaban parte de la élite -campesinos y artesanos-, el de las "clases subordinadas", tal como las catalogó Gramsci (Burke, 1991, p. 29). De ella se nos ha legado una imaginería popular caótica, desenfrenada y, en su fuero interno, descreída frente a la cultura dominante: la orquestada mayormente desde la Iglesia. También, transmitido indicios de una mentalidad a merced de una retroalimentación circular en referencia a dicha cultura dominante y sujeta a unas complejas mediaciones de la una con

\footnotetext{
4 De ahí que, con el ánimo de despejar esta borrosidad, Storey (2002, p. 19-37) hubiera propuesto seis formalizaciones de ella, tomando como criterio aquello a lo cual cada una dialécticamente se opondría.
} 
la otra que no se atiene al tópico de una reproducción mecánica tout court. ${ }^{5}$ Piénsese que la cosmovisión alternativa que caracteriza al universo popular -aquella extraoficial a la dibujada desde la Iglesia, circulante por los intersticios que esta institución no habría obturado y que Bajtín (1990) verá expresada en la iconografía de Rabelais- delata un prisma de encriptada incredulidad y semiclandestina ridiculización de un sistema ideológico cristiano no por entero, como en apariencia pudiera pensarse, hegemónico. ${ }^{6}$

En relación al primer registro antes indicado, el forjado en el seno de las élites intelectuales adscritas ad hoc al campo religioso, cabe afirmar que el trasunto de $I S$ de pueblo es indisociable de su ensamblaje con la Cristiandad como IS central. Presentada ella, por antonomasia, como la instancia transcendente, simbólicamente instituida y elevada en su arbitraje por encima del reprochable capricho, orgullo o amor propio de la individualidad de los creyentes en cuya conciencia anida, fuentes de los mayores vicios y desgracias convivenciales. Cristiandad concebida como una hermandad encarnación mística de Dios y cuya comunión con ella será el aval de un signo integrador en el ordo comunitario (Guriévitch, 1990, p. 313-333).

A inicios de s. XI, Adalberón de Laon y Gerardo de Cambrai, dos influyentes obispos afincados en Francia serán los artífices de las bases intelectuales del más firme sistema ideológico instituido en el Ancien Régime. En realidad, este sistema no deja de ser una modulación emuladora del esquematismo trinitario del cual Dumézil se había servido para escudriñar la quintaesencia más originaria de la cultura indoeuropea. Trastocado el imperio carolíngio, se trata de la más elaborada sistematización doctrinal legitimadora de la organización social surgida de la Revolución feudal, alargando su radio de influencia de sobremanera en el Ancien Régime. En su interior se anuncia un esquema ternario, fruto de la culminación de cuatro sistematizaciones preliminares, triangulado sobre tres ordos: oradores, guerreros y labradores. Piénsese que el término ordo es de procedencia y patrimonio carolíngio, en consonancia con la mentalidad religiosa precedente a la instauración del feudalismo. Tras siglo y medio eclipsado, el sistema reaparecerá con vigor a mediados de s. XII, regularizándose en los primeros Estados Generales, en los albores de s. XIV. En este se certifica una trifuncionalidad encomendada a la actividad desempeñada por los tres estratos en la jerarquía social. El Clero consagrado al servicio de Dios. La nobleza dedicada a la conservación del Estado. El Tercer Estado, más del 90\% de la población, aplicado tanto a la manutención, mediante el cultivo de la tierra, como a la guerra.

A comienzos de s. XVII, Carlos Loyseau, en una tesitura aún trufada por la negativa visión del trabajo arrastrada de la antigüedad, sofisticará todavía más este sistema, haciendo

\footnotetext{
5 Tal como atestigua el paradigmático semblante contestatario, ayudado por el auge de la imprenta y la ola de cuestionamiento de la dogmática católica alentada por la Reforma protestante, de Doménico Scandella, conocido como Menocchio, molinero a la sazón condenado a muerte por un tribunal eclesiástico en el siglo XVI (Ginzburg, 1999).

${ }^{6}$ En el paréntesis comprendido entre los s. XVI y XVIII esta cultura popular acabará siendo poco a poco desarticulada desde un abanico de frentes: a) La expansión de la revolución comercial asociada al capitalismo. b) El acceso a la educación promovido por la Iglesia. c) El fomento de una interesada conciencia política en el pueblo. d) El proceso de su renuncia por las clases altas: Clero, nobleza y burguesía (Burke, 1991, p. 343-396).
} 
ver que la dedicación específica de cada estrato social respondía como precepto a una plural llamada de Dios: orar, combatir y trabajar. Con esta reescritura se apuntalaba la legitimación de unas relaciones jerárquicas en base a una desigualdad natural de partida que, a su vez, nos reconducía a un fundamento de signo teológico (Duby, 1980, p. 165). ${ }^{7}$ El sistema se mantendrá hasta la gestación de la economía mercantil y el auge adquirido por un estilo de vida urbano que, con la mutación de los villanos en burgueses, depreciará la estimación antaño asignada a la tierra en el marco del feudalismo; herencia consecuente del antiguo latifundio romano y más tarde del señorío medieval.

En lo que aquí concierne examinar, este sistema ideológico, manufacturado en los adentros de la Iglesia como órgano monopolizador de la producción y difusión de la cultura oficializada, ayudará a prefigurar un protoIS de pueblo enmarcado en una cosmovisión trifuncional del organigrama social. En este escenario, pueblo se equipará con un campesinado sujeto a un compromiso de subordinación contraído con la nobleza: con los también llamados villanos. Con todas las reservas que merece la recepción de la tesis lanzada por Duby, resulta de utilidad para indicar orientaciones acerca de cuál fue la consideración del lugar natural de pueblo en la mentalidad del Ancien Régime, con anterioridad a la conformación de un IS, propiamente dicho, en torno a este hijo de la modernidad.

\section{La irrupción de la categoría de pueblo en la modernidad}

Poco entenderíamos, siguiendo el móvil de la historia conceptual, de las más destacadas modulaciones de pueblo en la época moderna si no las interpretásemos a la luz del devenir de las dos grandes significaciones centrales sincrónicamente emergentes en esta época, reemplazando las cualificaciones conferidas al universo mítico greco-romano o al Dios cristiano: la racionalización económico-administrativa y la autonomía individual conquistada por medio de la ruptura con la tradición. Con la modernidad, la eclosión del elenco de identificaciones de la sustancia de pueblo, de la pluralidad de sus encorsetamientos en una arbitraria definición, precisarán ser leídos a resultas de su nexo con estas dos significaciones centrales. El IS de pueblo, en sus variantes canónicas comparecidas en la época moderna, mantiene una urdimbre con el maridaje sellado entre ambas, siendo un fruto resultante de su conjunción. En especial de la enarbolada ecuación, según la cual la confianza cifrada en la racionalidad científico-técnica repercutiría directamente en unas crecientes cuotas de emancipación histórica. ${ }^{8}$ En gran medida, la particularidad de estas variantes derivará de una diferente toma de posición -adhesión, repulsa o contradictoria ambivalencia- con respecto a la trabazón de estas dos significaciones en dicha ecuación.

\footnotetext{
${ }^{7}$ En un mundo casi por entero tutelado por la religión, el protagonismo de la visión trinitaria de los ordos se justificaba en base a la voluntad divina, exhibiéndose como un canon modélico que, en una fiel transposición del macrocosmos, revelaría cómo debiera ser concebida una formación social (Huizinga, 2001, p. 77); aunque, a decir verdad, la clave real, la política, de su propósito fuera zanjar la disputa esgrimida entre el carisma chamánico de la clerecía y el valor guerrero de la caballería, procurando doblegar los guerreros a los clérigos para hacer a los primeros protectores de la Iglesia (Le Goff, 1999, p. 234-235). 8 De espaldas a sus potenciales efectos disuasorios, insuficientemente transparentes para la época (Foucault, 1967; 1994).
} 
En adelante, examinaremos la caracterización de las cuatro fórmulas canónicas asumidas por el IS de pueblo en la Edad Moderna: 1) La Ilustración. 2) El nacionalismo. 3) Los movimientos sociales desprendidos de la Revolución industrial. 4) La democracia.

\section{1. El proyecto ilustrado: IS de pueblo como sujeto político}

A partir del s. XVIII la construcción del $I S$ de pueblo será responsabilidad de las élites ilustradas de impronta burguesa, en contra de la enemiga natural en su propósito por entronizar el Estado: la Iglesia católica. No así en contra de las Iglesias protestantes, al ser ellas representantes de una nación y estar coaligadas con los Estados. Como es sabido, en Francia estas élites enarbolarán una emblemática defensa de los principios republicanos de ciudadanía que se amparará en una prelación axiomática de la libertad e igualdad del individuo ante la ley. Si bien una defensa puramente formal, dado que soslayará el posicionamiento previo de los individuos en la escala social, a su vez dependiente de su encuadre en el campo económico. Este $I S$ de pueblo se entroncará en el ideario de un despotismo ilustrado comprometido en políticas de centralización y racionalización de las funciones del Estado, y en el que dichas élites intelectuales adquirirán un especial protagonismo. Si, como ha mostrado Anderson (1992, p. 36-37), el Estado Absolutista, aparecido en el s. XVI, logra perpetuar indemne la arquitectura de dominación feudal del medievo mediante la incorporación de una nepotista maquinaria de Estado -con sus ejércitos, funcionarios y tributos- en una época de transición al capitalismo, entonces queda esclarecido el verdadero rostro del despotismo ilustrado. Con anterioridad a que los revolucionarios franceses consiguiesen plasmar políticamente su ideario republicano, éste debiera ser entendido en virtud de un conjunto de reformas emprendidas por las monarquías absolutistas -José II, Catalina II, Carlos III y sobre todo Federico II en Prusia- destinadas a reciclar los privilegios supervivientes de la estructura estamental feudal. Con este empeño se comprometieron en políticas de cuño paternalista encarriladas al aumento de la prosperidad socioeconómica. A su modo, los intelectuales adquirieron protagonismo en la realización de este plan, entablando una complicidad con los poderes gubernamentales. Para decirlo sin rodeos: «El defecto estaba en que la filosofía creía servirse de los reyes y eran los reyes los que se servían de ella» (Hazard, 1998, p. 294).

Llevados por la ola de un optimismo histórico sin precedentes y embargados por una ciega fe en el progreso en boga en la atmósfera de la época, los intelectuales ilustrados estarán vivamente comprometidos en un apostolado cifrado en dar curso a un $I S$ de pueblo identificado con la ciudadanía política enmarcada dentro de los márgenes territoriales de un Estado. Una tarea que ellos delegarán en la educación, cuyo fin último pasará a ser la formación nacional de ciudadanos al servicio del Estado-nación. En lugar de desempeñar el papel que hasta entonces le fuera asignado -servir de filtro para la reproducción de un seleccionado círculo de clérigos-, la educación se convertirá en una prolongación logística de la política tutorada por el Estado. No en vano, el símil de fondo entre el clérigo y el funcionario se trasluce en que ambos se consagran a un denominador común: el ejercicio de un officium. Esto otorga una inherente legitimidad a sus acciones, por el mero hecho de que 
ambos están investidos para ejercitar una explícita función, con independencia del estatuto moral de quién la ejerce (Agamben, 2012, p. 35-46).

El IS de pueblo quedará canonizado por Rousseau: una asociación de individuos formando una unidad en un solo cuerpo político que se ve traducida en una unánime voluntad general sellada en un pacto social, mediante el cual se da preferencia a lo común sobre lo particular; con la añadidura del papel del Estado como órgano representativo de dicha voluntad y, por consiguiente, garante de la integridad del cuerpo colectivo (Rousseau, 1988, p. 16). En este sentido, la idea-imagen fuerza de pueblo en su concordancia con la nación no solo se erigirá en un potente símbolo identitario unificador de los valores del jacobinismo, sino que concluirá siendo objeto de adulación (Baczko, 2005, p. 39-46). La concordancia entre el $I S$ de pueblo y la soberanía nacional servirá, así, de reafirmación al Estado-nación. ${ }^{9}$ La materialización final del programa de universalización del IS de pueblo como sujeto político se alcanzará con el cierre de un fleco abierto: la incorporación del Tercer Estado en el ámbito de la ciudadanía, de lo común (Sièyes, 2003, p. 90).

A la par y en una dirección pareja, en Prusia, por su parte, Hegel (1981, p. 259-275) se preocupará por justificar un $I S$ de pueblo en donde una objetivación de la entidad de este solo se cumpliría dentro de los parámetros de lo político, puesto que únicamente mediante la traducción en un Estado se consumaría de lleno la autoconciencia de eticidad de una comunidad, el grado máximo de "comunidad ética". Con la figuración como Estado el pueblo se toparía con lo universal, rebasando la parcialidad en la motivación que acompaña al funcionamiento de las restantes instituciones. Un pueblo sin la tutela del Estado sería no otra cosa, pues, que una entidad indefinida y todavía inmadura.

A la vista de lo cual, la distinción señalada por Agamben (1998, p. 225-229) entre Pueblo y pueblo pudiera resultar, a este efecto, crucial para desvelar el empeño moderno por cincelar el IS de pueblo en tanto sujeto político. El pueblo, a priori refractario a ser absorbido y encorsetado en la identificación del molde del Estado-nación, es impelido a redefinirse desde este molde, adquiriendo, de este modo, la fisonomía de Pueblo y desvalorizando el eco de aquello que, desde entonces, resuene a pueblo.

\section{2. El relato nacionalista: IS de pueblo como singularidad nacional}

Los valores puestos en liza por el universalista, more abstracto, ideario republicano de origen francés pronto tendrán una réplica reactiva consiguiente en el nacionalismo. En esta se preconizará un $I S$ de pueblo coligado a una singularidad cultural, a un "espíritu del pueblo" (volksgeist), que se forja en la tradición, reivindicando aquellos aspectos vernáculos defenestrados desde la versión del mundo ilustrada. De aquello que por ser lo más particular,

\footnotetext{
9 Según Arendt (1998, p. 25), esta herencia rosseauniana será un lastre que «derrota a la revolución en Europa antes incluso que hubiese hecho su aparición» y que consigue que devore a sus hijos. No sin motivo, explica Crossman (2003, p. 18-54), el estadio embrionario del Estado-nación fue la monarquía absoluta y su originaria legitimación la amparada en el derecho divino de los reyes.
} 
es lo menos comprensible a todos e imitable simultáneamente en cien lugares (Starobinki, 1998, p. 31-32). Martínez Marzoa (2018) ofrece una inmejorable pista para descifrar el porqué de una factible reactividad a la lectura ilustrada de pueblo. Arguye que la noción de sociedad civil resulta inseparable de la modernidad. En esencia porque se entiende en correspondencia con la presunción general de que existe un modo de ser de las cosas que las hace intercambiables entre particulares, en un isomorfismo con el tratamiento que de ellas se hace en el modelo de ciencia fisicomatemático, dejando así entrever la ausencia de contenidos realmente vinculantes, anclados en una determinada localización y necesariamente singulares.

Pues bien, el IS de pueblo de cuño nacionalista tendrá una raigambre fundamentalmente germánica, enmarcado en una apelación al renacimiento de una unidad alemana, en su diferencia neutralizada por el credo universalista del cosmopolitismo napoleónico. Una tensión, separada por un límite oscilante, entre una identidad dual conformada entre universalismo y particularismo que, por otra parte, salpicará a nuestros días (Beriain, 1996, p. 295). Es sintomático que, en el idioma alemán, a diferencia de citoyen francés o grashdanin ruso, no se halle un vocablo certero sinónimo equivalente al de ciudadanía (Lukács, 1969, p. 47-48); acaso porque, bajo la imborrable huella del luteranismo, la cultura germánica se haya enardecido de la profundización en un subjetivismo espiritual en el que lo político es visto como algo profanador, alienante y des-nacionalizante (Dumont, 1987, p. 146-147). De modo que, llegado el caso, esta huella luterana podría arrastrar a la nación alemana a un mesianismo político redentor (Cortés, 1996, p. 149-150). Esto es porque en Alemania el término Civilización se vio solapado por el de Cultura. Con este último se ha aludido a las realizaciones humanas comprometidas con la prosa orgánica de un pueblo en singular y en las que se traduciría la autoconciencia identitaria de una nación (Elias, 1989, p. $57-72) .{ }^{10}$

El romanticismo germánico elaborará un $I S$ de pueblo en donde se aupará un sentimiento de conexión con una herencia cultural primigenia, mitológica y local (el Volk alemán o el Narod ruso), haciéndola pasar como la seña de identidad esencial del ethos de un pueblo, aunque, a decir verdad, su propósito no fuera otro que el de contrarrestar la alienación de lo comunitario fruto de un nexo colectivo basado en una racionalidad contractual (Inneraty, 1993, p. 47-48). Por ejemplo, Herder (2007, p. 95-96) o Fichte (1994, p. 139) harán una decidida apología de la visceralidad del sentimiento -condensada en el mito, el arte, la religión, en lo más prístino- como sostén del auténtico patriotismo y frente al

10 «Toda cultura tiene unas posibilidades de expresión que se manifiestan, maduran, se marchitan y jamás se repiten... Estas culturas, seres vivos del mayor rango, se producen dentro de una noble indiferencia, como las flores en los campos; $y$, al igual que las flores en los campos, pertenecen a la naturaleza viva de Goethe y no a la naturaleza muerta de Newton» (Spengler, Untergang des Abendlandes, Munich, 1920, I, 28, citado en Elias (1989, p. 538)). No es de extrañar que Heidegger, bastantes años después y recogiendo este testigo contramoderno alemán, hubiese alentado a la recuperación de una encandilada organicidad de la cultura en la que sí encontraría su autenticidad y diferenciación el pueblo; y que solo ciertos poetas, a contracorriente de un mundo gobernado por la alianza entre la ciencia y el Estado total -un sucedáneo del Estado-nación-, parecieran poseer el don de desvelar. «Una casa, según la concepción americana, una manzana americana o un racimo de uvas de los de allí, no tienen nada en común con la casa, el fruto, el racimo en el que se habían introducido la esperanza y la meditación de nuestros ancestros» (Rilke, Cartas desde Muzot, 335 y ss., citado en Heidegger (1996, p. 262). 
fracaso ocasionado por la implantación de la frialdad del lazo vinculante instado a resultas de la calculadora e instrumental razón burguesa, en una nostálgica tentativa recuperadora de la Gemeinschaft..$^{11}$ Luego, a mediados de s. XIX, este IS de pueblo quedará ya apuntalado bajo una objetivación política como Estado encargado de vertebrar la identidad de un concreto territorio (Hobsbawn, 1991, p. 46-48). En el encuadre situacional anteriormente descrito, la enervación de la conciencia nacionalista alemana se sazonará de la utópica idea de que Alemania pudiera y debiera alzarse en portavoz de un nuevo orden. Eso sí, ahorrándose un anterior paso comprometido con la consumación de sus deberes de independencia política: los relativos al barrido de los Junkers feudales y el Absolutismo de los Hohenzollern (Lukács, 1969, p. 31).

El efecto más notorio resultante de la Edad Moderna sobre la textura de simbólica de la sociedad fue la pérdida de la densidad vinculante habida entre sus integrantes a resultas del punto de inflexión histórico que supuso el tránsito de una sociedad agrícola a otra industrial, con un consiguiente desalojo de la sustantividad y certidumbre absoluta en otra hora concedida al sistema de creencias religioso (Gellner, 2001, p. 89-116). El IS de pueblo reconocido en una singularizada identidad nacional emanará como un proyecto que buscará reestablecer la densidad vinculante de antaño, proponiéndose como un renovador código unitario autorrepresentacional que, en último término, no será más que una variante profana de sacralidad (Beriain, 2000, p. 92-101). Así, el IS de pueblo como sinónimo de nación se oferta como fórmula de certidumbre, como verdad sustantiva y absoluta, que anhelará servir como antídoto contra la contingencia en un mundo de facto secularizado y al albur de la incertidumbre; o, para decirlo de otro modo, que ansiará la empresa de «transformar el azar en destino» (Anderson, 1993, p. 29). Esto explica el parentesco de fondo entre religión y nacionalismo, así como la convergencia en ambos por fraguar un sólido sentimiento de hermandad fraternal entre sus acólitos.

\section{3. La sociedad industrial: IS de Pueblo equivalente a clase social}

En la segunda mitad de s. XIX aparece en escena un IS de pueblo coincidente con el proletariado. ${ }^{12} \mathrm{Si}$ se quiere se retoma un arrinconado significado originario de pueblo: el que

\footnotetext{
11 Qué duda cabe que la naturaleza del IS de pueblo, visto como sinónimo de una coloreada singularidad nacional encaminada ex profeso a la recuperación y utilización de una herencia cultural autóctona, respondió a la invención de un relato de cariz mítico encuadrado en un preciso paisaje histórico y de cuyo examen rezumaría su verdadera razón de ser. No en vano es sintomático que la presencia de este $I S$ hubiera resonado con energía en Alemania más que en otra latitud europea. Un país que, hasta bien entrado el s. XIX, acumula un retraso industrial que pretenderá ser luego subsanado aceleradamente, que está marcado por la supervivencia de resabios idiosincrásicos de sociedades semifeudales en un mundo instalado en la modernidad y que imagina la instauración de recursos simbólicos al servicio del logro de su unificación identitaria

12 Por más que convenga precisar que, desde sus inicios, esta coincidencia no ha sido del agrado de toda la intelligentsia. No, porque una vez racionalizado y objetivado el pueblo en una resignificación en clave de clase por obra de la teoría marxista se hubiera dado un decisivo paso adelante en la superación de la dialéctica entre clases capitalista, sino justamente por lo contrario. Esto es porque un espontáneo espíritu insurreccional y de revuelta distintivo de lo popular, del pueblo digámoslo así, una vez dialectizado en
} 
aludía a la Plebs. La construcción de este IS será obra de una intelligentsia revolucionaria comprometida con las desventuras sufridas por el proletariado. La miscelánea ideológica involucrada en la lectura de los desarreglos desencadenados en esta fase del capitalismo, amén de un horizonte orientador de la praxis de los más castigados por la sociedad industrial, es irreductible a cualquier esquematismo al uso. El laberíntico maremágnum en donde cohabitan se amalgama y colisionan discursos de marca ideológica tales como el socialismo utópico, el marxismo o el anarquismo, junto a otros menos canónicos, es notorio. Con todo, la restricción unívoca del $I S$ de pueblo con la clase proletaria será un denominador común a prácticamente todos ellos. Tomaremos como referencia paradigmática el armazón de la versión marxista del $I S$ de pueblo.

Primeramente, como reacción frente a un $I S$ de pueblo en donde se omitía la dialéctica entre grupos sociales con intereses confrontados, se enfatizará la necesidad de incorporación de un decisivo elemento estructural de clase en este $I S$. Marx entendía que «la clase proletaria es la común representante del pueblo» (Marx, 2010, p. 11-12). ${ }^{13}$ Para él esto obedecía a que el proletariado representaba el interés universal de toda la sociedad ${ }^{14}$, elevándose por encima de la inmediatez y el bajo vuelo de los intereses particulares correspondientes a los restantes sectores sociales. ${ }^{15}$ Por eso, Marx y Engels (1974, p. 52-53) dictaminarán que el proletariado «se contrapone intrínsecamente a una clase», dado que debiera ser visto, con exactitud, como "clase universal"; afirmación jalonada con otra según la cual «el movimiento proletario es el movimiento autónomo de una inmensa mayoría en interés de una mayoría inmensa» (MarxEngels, 2013, p. 63). No olvidemos algo sumamente importante: que la categoría de clase señala, inequívocamente, hacia un futuro (Koselleck, 1993, p. 109). Pero lo auténticamente decisivo, como dirá con una mayor precisión Lukács (1975, p. 49-122) al calor de las expectativas históricas suscitadas por la Revolución rusa, lo que determina que el interés del proletariado se equipare con el del pueblo, es la misión histórica a la cual esta clase se consagra: el vuelco histórico cualitativo que daría paso a un futuro modelo social

términos de clase y responsabilizado de una finalidad histórica, habría declinado. Arrastrado por esta sinergia, el proletariado, ahora acotado en una categoría de clase, se vería forzado a desarrollar su lucha política en el campo de juego preestablecido a priori por el orden burgués y con unas reglas desde tal orden impuestas; lo que, en último término, adocenará y contendrá su originaria energía revolucionaria (Baudrillard, 1996, p. 162 y ss.). Para decirlo en lenguaje de Deleuze y Guattari (1994, p. 213-235), la diferenciación entre masa y clase, ahora formalizada por ellos en términos metafóricos de "molecularidad" y "molaridad", implicaría que una potencia inscrita en la masa sería irreductible a una codificada segmentación de clase.

${ }^{13}$ Pero, como ha sostenido Bueno (2008), resulta difícil de admitir una clase universal -el proletariadoequiparable al género humano, un pueblo histórico identificado con el destino de este género, así como una dialéctica de clases inseparable de una enconada dialéctica entre Estados; tal como quedó mostrado en el enfrentamiento entre el proletariado alemán y el francés a raíz de la conflictividad bélica desatada en las dos guerras mundiales que azotaron el pasado siglo.

${ }^{14}$ A despecho de que en Crítica del programa de Gotha, en polémica con las estrategias socialdemócratas propugnadas por Lassalle, Marx (2000, p. 19-20) hubiera flexibilizado este criterio, sugiriendo ensanchar este espacio e incluyendo a las capas medias en su tránsito inminente al proletariado, artesanos, pequeños industriales y campesinos. De ahí, asimismo, el ulterior empeño por parte de Lenin en extender la acotación del espacio definitorio de clase proletaria, admitiendo al campesinado.

${ }^{15}$ Repárese, por otra parte, que en los adentros de la metáfora de la inversión (Umstülpung), empleada frecuentemente por Marx y Engels en su crítica a la filosofía del espíritu hegeliana, se mantendrá el resabio de "clase universal" acuñada por Hegel, si bien trasladando su sinonimia desde la imparcialidad de los servidores civiles del Estado hacia el proletariado (Bueno, 2017, p. 109). 
caracterizado por la superación de la economía como un "poder social extraño" y, consiguientemente, por la mutación del "reino de la necesidad" en un paradisíaco "reino de la libertad". ${ }^{16}$

Pero, además, el IS de pueblo puesto en circulación por la teorética marxista denunciará que en las versiones de cuño universalista del Estado de raíz burguesa el pueblo no se equipará más que formalmente con el Estado. Sin una presencia más que nominal del proletariado en la confección del pacto social burgués, el Estado no representaría, imparcialmente, a interés general alguno, antes bien su actuación estaría subordinada al interés de la burguesía como clase dominante. En las represalias estatales a consecuencia de los desmanes de orden público estallados por la aparición de La Comuna parisina o en el golpe de mano desatado por Luis Bonaparte, el objetivo de Marx (1970; 1975) será desenmascarar el partidismo de clase del Estado. Por tanto, la intelligentsia marxista hará ver que la única fórmula política viable para el logro de una equivalencia real entre pueblo y Estado vendrá dada por el vuelco histórico antedicho, con el que por fin desapareciese una formación social sustentada sobre una arquitectura de clases. ${ }^{17}$

\section{4. Evolución de la sociedad moderna: IS de pueblo objetivado en la democracia}

Con la conclusión de la II Guerra Mundial emergerá un IS de pueblo igualado a la democracia. Esta, a mayores de su dimensión propiamente procedimental (Schumpeter, 1983), devendrá algo más: un fin orientador, un "ideal moral" (Durkheim), forjador de valores vinculantes. En efecto, desde la Grecia Clásica ha habido una especulación en torno a la legitimidad de la democracia como sistema de gobierno, sopesando sus virtudes y defectos. Pero lo acaecido con el punto de inflexión antes señalado será la elevación de la democracia al rango de un $I S$, erigiéndose en vértice angular dimanante y articulador del significado global de la experiencia colectiva, y encumbrándose como «concepto universal de orden superior que, al sustituir a "república", relega a la ilegalidad como formas de dominación a todos los demás tipos de constitución» (Koselleck, 1993, p. 115-116).

En los albores de la década de los ochenta del pasado siglo, ya definitivamente aceptado el fracaso político del comunismo soviético, las versiones neo-formalistas de la democracia comenzaron a calar con fuerza en el concierto de la teoría política europea, ejemplificándose en los paradigmáticos planteamientos de Habermas -“comunidad ideal de diálogo"- y Rawls -"velo de ignorancia"-. En ambos hubo una obstinación por enfatizar la validez de una facultad deliberativa que, basada en una racionalidad argumentativa preaceptada por los interlocutores, sería capaz de consensuar una universal y desacralizada

\footnotetext{
16 Aunque quede sin cerrar algo más que un fleco: la aclaración del perfil normativo de la bondad o justicia a la que la meta aspira (Ovejero, 2018, p. 111-154).

${ }^{17}$ Esta será la legitimación en la que luego se respaldará Lenin (1997, p. 45-48) para dar carta de naturaleza a la dictadura del proletariado, pero también significará un punto de permanente discordia con los teóricos de inclinación anarquista como por ejemplo Proudhon (p. 356-445), quien había abogado por la defensa de asociaciones de productores bajo cooperativas autogestionadas según principios de mutuo acuerdo, sin coacción y en base a instituciones solidarias marcadas por la igualdad y reciprocidad.
} 
axiomática normativa dirimida en el marco del espacio público. Empero, estas propuestas sobrestimarán el don de la razón como guía rectora en el campo de la acción colectiva. Pero, además, orillarán que un insoslayable motivo de la abnegada adhesión a la democracia residirá en la sustantivación de sus premisas como $I S$ determinante de una «significación imaginaria» unánimemente compartida, en el sentido mentado por Castoriadis; o como «narrativa imaginaria» legitimadora de la identidad de una sociedad política (Taylor, 2018, p. 103-104). Sobre todo, este $I S$ sostendrá, como parte reglada "no contractual e inexplícita" (Durkheim), un consenso normativo; siendo, al cabo, la "transcendencia inmanente" sobre la cual dicho consenso se asienta. Esto no es algo nuevo, puesto que ya la aguda mirada de A. de Tocqueville (2006, p. 123-187) descubriera la indisolubilidad más que manifiesta entre democracia y religión. De lo que se deduce una propensión a la sacralización, a la absolutización inmanente, de la democracia, inmersa en un proceso más generalizado de absolutización de esferas de lo político profano, tales como Ideología, Utopía o Partido. Esta sacralización obedecerá a la conversión de un tipo de régimen político en una articulación imaginaria en torno a la cual se integra, argamasa y cohesiona el pueblo. Finalmente, esta convicción en la democracia acabará fundiéndose con el refuerzo de la identidad colectiva.

Hay una camaleónica persistencia del formato religioso en las entrañas de lo político moderno. Se vislumbra una modificación en la economía de la representación, desplazándose la vieja encarnación de Dios en la figura del monarca por una otra basada en una delegación entre iguales (Gauchet, 1998, p. 13-14). Esta semántica religiosa incrustada in essence en la democracia explicaría que esta entrañe una transposición de la omnipotencia de Dios a la soberanía del pueblo, lo que ha podido dar alas al acogimiento de una Teología política (Schmitt, 2009), así como a la consideración suya como transmutación de un ideario gnóstico mesiánico-utopista (Voegelin, 2006, p. 195-225). Pero acaso lo más acertado sea reconocer este formato religioso antedicho ahondando en la inherente metamorfosis adosada a la noción de "religión civil" rousseauniana, indagando en la naturaleza de aquellas brújulas orientadoras de lo social con fisonomía religiosa por el hecho de que a su presencia se le atribuye la capacidad de despertar una generalizada funcionalidad consensual, estando enraizada en las directrices de una cultura política (Lübbe, 1983, p. 79-107). Así, este IS de pueblo objetivado en la democracia urdiría un ethos comúnmente compartido por una colectividad, garante estabilizador de su unidad vinculante; en suma, este IS se autoconstituirá en el lazo simbólico sobre el cual se vertebra una sociedad política. En un célebre dístico, Hegel le adjudicara a Goethe la pregunta: «¿Qué es lo sagrado? ». Y la respuesta del literato y pensador germánico fue tajante: «Lo que une a muchas almas juntas» (Hegel, 1975, p. 638). Precisamente en esta facultad radica el motivo del peligro de que la democracia devenga en fundamentalismo (Bueno, 1997, p. 29), hipostasiándose y divorciándose de su originario leitmotiv auto-instituyente. Auto-institución vacunadora frente a la declinación hacia una deriva sacralizadora suya, pero también, por lo mismo, hacia una análoga dirección de cualquier otra enunciación política. 


\section{El declive de las construcciones modernas del $I S$ de pueblo y sus repercusiones sociopolíticas}

Siendo fieles al desiderátum arrojado por las directrices de la historia conceptual, la hipótesis analítica aquí sugerida incidirá en la constatación del desfonde de la vitalidad de los relatos de pueblo que, tallados desde unos correspondientes $I S$, fueran edificados en el curso de la modernidad para dar una conformación sustantiva a la, de principio, indescifrable indeterminación de pueblo. En consecuencia, en la evidencia de una pulsación del despunte de un flujo de aspectos de acento afectivo-emocional -llamémosle así- extendidos por la experiencia colectiva que, acaso a la espera de una más fina conceptualización, agruparíamos bajo el apelativo masa, siendo conscientes del retome de un vocablo, ya un tanto desgastado por su largo uso en el periplo de las Ciencias Humanas y Sociales. ${ }^{18}$

La masa aquí referida, muchedumbre sumamente viscosa empapadora de una amplia gama de escenarios colectivos, invita a ser pensada de acuerdo con los siguientes trazos: 1) Un extremado proceso de individuación paradójicamente hibridado con la efervescencia de una abigarrada constelación de microidentidades sociales. 2) Un distanciamiento, o al menos una revisión, de las atribuciones encomendadas al papel de un monocromático sujeto histórico al estilo del aupado en la modernidad. 3) Una indiferencia post-política hacia lo político nutrida del reavive de un lenguaje contaminado de elementos pre-políticos. 4) La enaltecida comparecencia de unos carismáticos aspectos emocionales y sentimentales en el adentro de las dinámicas colectivas.

Echando mano de un ilustrativo símil metonímico con el léxico aristotélico, esta masa sería materia que pareciera reivindicar una condición a-morfa, resistente a la adopción de una completud bajo una forma moderna. Masa será el resto sobrante que queda tras haber exorcizado de pueblo, entre otras designaciones con una menor entidad, las de sujeto político, singularidad nacional, clase o democracia. Así vista, masa es, sobre todo, pura indeterminación, vacío, en un estado potencial para su adhesión a una determinación. Pues bien, no estaría desencaminado abordar su idiosincrasia como un arquetipo metafórico que, apegado a nuestro horizonte histórico, abrace diversas sedimentaciones, reveladoras, en su aspecto global, de una «saturación del orden de lo político moderno» (Maffesoli, 1990, p. 95-

\footnotetext{
18 De entrada apuntalar que lo que con este apelativo se conjetura no es la turba mimética que dejó aflorar su rostro en la vida pública con ocasión de las revoluciones desatadas en la Edad Contemporánea, tan vituperada por autores amantes del orden como Taine u otros; ni la embriagada que embargó la alocada revuelta de movimientos sociales durante la segunda mitad del s. XIX, motivando el asombro de Le Bon y Tarde; ni la descarga de una contagiosa enervación societal sobrevenida en aconteceres puntuales more del retrato de Canetti; como tampoco la mediocridad arrastrante hacia una pendiente de degradación cultural de nuestro Ortega y Gasset. Más correctamente, un perfil de esta masa se adecuaría a lo que en sí ella contiene de insinuación a una "zona de sombra" (Jung) autonegada o gestionada más mal que bien por la modernidad. Una pista sí provechosa para el descifrado de su peculiaridad sociológica es la suministrada por el filósofo alemán Sloterdijk, eximida de enaltecimientos e impermeable a enjuiciamientos éticos: «Su estado es comparable al de un compuesto gaseoso, cuyas partículas, respectivamente separadas entre sí y cargadas de deseo y negatividad pre-política. Oscilan en sus espacios propios, mientras, inmóviles ante sus aparatos receptores de programación, consagran individualmente sus fuerzas una y otra vez a la solitaria tentativa de exaltarse o de divertirse» (Sloterdijk, 2002, p. 17-18).
} 
96). ${ }^{19}$ Para lo que nos concita, una masa vista como un inconceptuabilizable magma reticente a ser encerrado en la declinación de las emblemáticas semánticas modernas de pueblo. Que por ello deja transpirar una faceta de pueblo con visos de des-absorción en el repertorio de las configuraciones que, a través de la operatividad de los $I S$ fungidos en la modernidad, de este se llevó a cabo. Que se advierte que escapa, desbordándolo, un alineamiento o adscripción a sus pretendidos constructos identitarios delineados en la época moderna. A modo de constante, las objetivaciones del libre curso de este arquetipo masa comparten una preferencia al rebasamiento del lenguaje categorial en el que se sostuvieron las traducciones de pueblo esculpidas desde los $I S$ modernos, incluyendo significativamente a las lógicas de su representación y a sus estrategias de emancipación consiguientes. ${ }^{20}$

Desgranaremos tres ejemplificaciones paradigmáticas en las que este arquetipo saldría recientemente a flote, apuntándosenos indicios de unas improvisadas intentonas de autodefinición y canalización de la sustancia de pueblo alrededor de unas expresiones reactivas a las cinceladas en la modernidad: 1) microidentidades. 2) multitud. 3) populismo. En adelante, desglosaremos sus atributos en función del desgaste de las principales caracterizaciones del IS de pueblo aupadas en la modernidad.

\section{1. El repliegue de pueblo en una proliferación de microidentidades}

Uno de los rasgos descriptivos de las sociedades de la modernidad más avanzada es la profusión de una heterogénea gama de continentes en donde se da una viva cabida a la expresividad del modus vivendi de un amplio, ecléctico y versátil mosaico de microidentitades. En ellas, la "lógica de la identificación” se eleva a un primer plano, favoreciendo el despertar de unas trayectorias comunes conducentes a la fijación de una

\footnotetext{
19 Aclaremos que, en aras de la concesión de una dignidad sociológica que en nombre de la masa en ocasiones se ha reclamado de ella -aunque resulte oscuro apreciar que de tal concesión pueda inferirse una mayor dignificación suya-, el diagnóstico de Baudrillard (1993, p. 109-136) no es perentorio. Concebida ésta como un inconceptualizable agujero negro en donde lo social se precipita, trasluciendo un grado cero de lo político y portando una esencia anómica a toda fuente orientadora de sentido (Baudrillard, 1993, p. 111-113). Ahora bien, por mucho que las masas hubieran sido un factor trascendente en los designios de la historia contemporánea -sino en ciclos históricos anteriores- sería sumamente discutible hacer de tal factor el baluarte para la defensa de algo así como una ontología política sobre este apuntalado; y sería aún más discutible la legitimidad por rezumar de este factor un espíritu de justicia con la masa que pase por la liberación de los intermediarios institucionales supuestamente adulteradores de sus inobjetables propósitos. A despecho de un esencialismo que hace de la apatía e inacción de la masa, de su negativa al sentido fuese del color que fuese, una fuente para la apología de ellas, acaso sea más adecuado encarar el reto de desentrañar su fenomenología en virtud de unas claves psico-políticas socio-históricamente determinadas. 20 Con lo cual nos vemos forzados a convivir con el desconcierto acerca de si estas tentativas de rebasamiento obedecen a un desgaste e inadecuación de los IS modernos de pueblo a unas emergentes aspiraciones del pueblo o si, antes bien, su brumosa fisonomía responde a unas falsificadoras expectativas societales alimentadas de la incompletud o fracaso, como se quiera, en la realización de los ideales modernos de pueblo. Pese a ello, el factor prioritario para que se cierna una sospecha en torno a la consistencia y verosimilitud de estas tales tentativas no es tanto su señalamiento de la erosión de los $I S$ modernos de pueblo como su parapetado en una indefinición o, tal vez, en una ausencia de fines hacia lo que se apuntaría con el rebasamiento de tales $I S$, no está tanto en lo que ellas, acaso buenamente, diagnostican como en lo que en ellas se adolece u omite a causa de tal rebasamiento.
} 
agregación identitaria. A resultas de lo cual, un lazo de lealtad y solidaridad, segregado de la particular socialidad entretejida entre sus miembros y a modo de réplica a una galopante individuación, cobrará un pronunciado relieve (Maffesoli, 1990, p. 157-164). Con independencia del juicio que este repliegue identitario en torno a lo más próximo mereciera -bien sea como excrecencia de futilidad estética segregada a consecuencia de un constatable descontento sembrado por la desafección con la narrativa política moderna o como potencia instituyente generadora y articuladora de estrategias de autoorganización comunitarias más apegadas a lo cercano-, lo cierto es que la particularidad de su mostración evidencia una desidentificación psico-política en torno a las circunscripciones simbólicas y categoriales en donde el pueblo se había encarnado en episodios históricos antecedentes, subordinadas ellas al auge de los Estados nacionales. En cualquier caso, en el repliegue recalcado la gramática política moderna en general, así como el nudo contractual cifrado entre individuo y pueblo en particular, no gozan de demasiada frescura, tornándose en espejos referenciales inservibles a la hora de sensibilizarse con unas novedosas sinergias colectivas que la deriva en la soberanía del Estado-nación desatendería y, en última instancia, motivando una actitud de indiferencia hacia ellos.

Con todo, la pulsación de la socialidad en ellas desatada pone de relieve un substrato fluido de in-determinación, de masa, congénito a la a-morfa sustancia de pueblo -o si se quiere de pueblo- que las determinaciones de los $I S$ en uso no están en disposición de ceñir (Carretero, 2018, p. 5-26). Un aspecto de pueblo sistemáticamente devaluado y marginado en el umbral categorial moderno, pero que aflorará en la faceta en apariencia más irrelevante y frívola de las manifestaciones de consumo identitario. Es más, un aspecto que, refractario a toda definición, ellas explotan y retroalimentan. Pero, lo más importante, un aspecto que da cuenta de la prevalencia que, en la oleada de nuevos formatos identitarios, habría adquirido el hervidero de sentimientos, afectos y emociones (Maffesoli, 2005, p. 163-176). Si, en verdad, la pasión en común, el sentir junto a los demás, es un manto freático que permite a la vida en sociedad ser lo que es (Maffesoli, 2005, p. 55-56), estas expresiones microidentitarias nos lo ponen de manera incentivada al descubierto, al priorizar en su ligamen vinculante a esa instancia in essence no-racional.

Se han hecho múltiples lecturas del embrujo en una fortificación micro-identitaria. No obstante, poco avanzaríamos en la descodificación de sus claves si no alcanzásemos a concebirlo como fruto de un elenco de tentativas, en el fondo psico-políticas, reactivas al curso de las modulaciones emblemáticas en las que el pueblo tomó cuerpo en la modernidad. Conviene tener presente que unas tentativas propiciadas a raíz de un fenómeno capital: la desaparición de la holística centralidad de sentido -léase religioso o metafísico- antaño eje nuclear de la cultura occidental y la consiguiente eclosión de una desproporcionada inflación de éste. Por tanto, enclavadas ellas en un mundo en donde, a resultas de la evolución última de la modernidad, el sentido se ha tornado descentrado, plural, fragmentado, diseminado en múltiples microrelatos colindantes en donde hallará albergue una multiplicidad de nichos identitários expandidos por una reticular cartografía social.

Con toda probabilidad, la revisita a esta fenomenología micro-identitaria llevada a cabo por Sloterdijk (2009) es aquella que, nuevamente, más habría profundizado en el carácter nihilista y reactivo a la modernidad inherente a su sintomatología. La metáfora más 
fidedigna a la cual él apelará para aclarar el retrato de las implicaciones sociológicas resultantes de la inflación de sentido es la de "espuma". La imagen remite a un paisaje cultural acéntrico y poliesférico compuesto por la coexistencia e interconexión de unas "burbujas" internamente invertebradas. En sus adentros se pretende rehabilitar un mundo común, un habitar compartido, fruto del hilvanado de unas co-implicaciones sustentadas en la intimidad e intercambio solidario de afectos. Del cual se desprende la efervescencia de unos sui generis microcosmos que, alojando unos lazos de afinidad tejidos entre sus integrantes, reafirmarán unos sentimientos pseudocomunitarios y, a su manera, identitários. En última instancia, las "burbujas" serían artificiales y frágiles receptáculos placentarios provistos para dar cobijo y congregar a un elenco de individuos atrincherados frente a la hostilidad del mundo circundante. Quienes las integran anhelan neutralizar esta hostilidad, aislarse de ella, mediante un repliegue auto-inmunizante en el seno de un receptáculo aclimatado en donde florece la interioridad, la originalidad, la creatividad y, en general, una dimensión de la experiencia intersubjetiva en la que se estila congraciarse con una autorrealización personal en la cercanía con algunos otros.

En lo que nos atañe, la subjetividad de la masa que ocupa el interior de estos protésicos micro-invernaderos no respira sentido transcendente, mandato teleológico o adhesión a principio cívico-político alguno, sino indiferencia hacia todo ello. Ella únicamente se avecina, y finalmente argamasa, en una intimidad impolítica ecológicamente compartida con otras subjetividades parejas, apuntalándose en la marca de un diferenciado estilo de vida. Así, la tendencia sociocultural perfilada hacia una aclimatada encapsulación en dichos microinvernaderos estaría evidenciando un manifiesto desafecto e impasible contrariedad con respecto al marchamo de la lógica representacional que había sido encaramada durante la modernidad, incluyendo, de manera más explícita, a la narrativa representativa de pueblo en su designación como sujeto político.

\section{2. La multitud: el presunto desquite del pueblo frente al Pueblo}

La reacción ante la percepción de un décalage, junto a un consiguiente descrédito, en la lógica de la representación moderna -incluidas las clásicas objetivaciones de pueblo- allanará el terreno para que se abra paso sociológico una particular masa de figura indefinida. Ésta, aglutinándose y extrayendo su fuerza de la coparticipación en una potencia destilada de un entrecruzamiento en una comunidad de afectos, no se reconocerá en los patrones políticos ideados en la modernidad como vías para dar curso a sus exigencias. En fechas relativamente cercanas, esto es lo que se ha dado en tildar como multitud. En efecto, una masa en toda regla, pero desmarcada de las vituperadas connotaciones decimonónicas asociadas a una muchedumbre impersonal, irracional, pasiva $\mathrm{y}$, sobre todo, manipulable. Si bien reincorporando una sustancia de lo social precedente, aunque aparentemente marginada, a la semántica política enaltecida en la modernidad. Esta fenomenología podría estar alertando acerca del fluir de un humus colectivo de marchamo impolítico, de un auténtico no-ser de lo político agenciado por el "gentío", aunque resistente a su traducción política bajo un auspicio moderno (Bergua, 2015, p. 15). En la mayoría de las ocasiones se ha querido forzar una 
hermenéutica discursiva de acento más político que impolítico de esta masa asimilada a la multitud. Con el propósito final de pretender encauzarla, muchas veces a regañadientes de ella, en las coordenadas de lo político. El cometido consistiría en hacer de ella lo que en su esencia actual no sería pero que se presumiría predispuesta a ser. Vale decir que se ha procurado introducir una identidad y definición en la indiferente diferencia e indefinición de la multitud, para que así ella asumiese una determinación ideológico-programática en el cuadro de una estrategia política-la rectora del anónimo trabajador postfordista-, aun cuando evidentemente distanciada del vector moderno de pueblo.

En las últimas décadas, el enfoque del marxismo a la italiana ha refrescado y revalorizado la multitud para transferirle una potencia de insurgencia política. La ha erigido en una categoría ontológica decisiva para repensar las estrategias de contradominación en la cartografía de las sociedades del capitalismo postfordista. Por ejemplo, Virno (2003) se ha empecinado en rescatar un carácter soberano, ni fallido ni desfigurado, de pueblo a partir de un realce antropológico de lo genérico, lo común, "lo transindividual" (Simondon). Una soberanía per se refractaria a su confluencia en una unidad política, en la que sí se habría dejado finalmente atrapar y acartonar la consideración moderna de pueblo. Él lo encuentra en la multitud: «una forma de ser, algo fundamental, básica, de relación con el mundo, con los otros, con la vida» (Virno, 2003, p. 130). Lo que, en verdad, nuestro autor detecta en ella es una categoría de sello ontológico de difícil trato para cualquier reductor esquematismo filosófico-político al uso. La "multitud" precedería -y post-cedería- al desiderátum de la representación contractualista moderna en la que el pueblo se habría tradicionalmente autorreconocido. A la hora de encender la unidad de una común acción colectiva, la multitud sería, tanto en lo concerniente a su concreción política como a la dirección del proyecto ideológico tomado, potencialmente ambivalente. Pudiera materializarse doblemente tanto en una entrega al espíritu de revuelta de La Comuna parisina de s. XIX como en la adhesión a los fascismos brotados en la primera parte de s. XX. Por ello, Virno, en un idóneo caldo de cultivo eventual, atisbará en la multitud la expectativa de un reconvertido sujeto revolucionario, des-identificado de un viciado marco de representación de pueblo fruto de su entronque con el Estado, alérgico a un ceñimiento y encaje en la unidad de lo político al modo moderno.

Por su parte, Negri y Hardt (2005) son más firmes y van más lejos en el programa de constricción y reconducción del flujo de una masa impolítica asimilada a la multitud en una positiva fuente de provecho para su encauzamiento político, en su articulación como un incipiente sujeto histórico. La multitud sería, en efecto, masa, pero masa, en contraste con una calificación más tradicional, caracterizada por dar acogida a una potencia inmanente configurada en virtud de una singularidad de multiplicidades dispuestas en un orden determinado (Negri, 2004, p. 113). El objetivo es destilar de esta masa, en cuyos adentros se destila una corriente interna de afectos, emociones y pasiones entrelazadas, el catalizador para el destape de un activismo político, del cual pudiera extraerse un telos apuntado a la realización de un poder constituyente, al logro de una supuesta democracia radical. De la mano de una renovada relectura de Spinoza enfrentada a la hegemonía del contractualismo de corte hobbesiano, en la controversia dirimida en el contexto de surgimiento del Estado Moderno, Negri y Hardt, como asimismo Virno, entenderán que el mayor activo ideológico- 
político atesorado en el rostro de la multitud estribaría en que, siendo está a menudo depreciada por constitutiva del "estado de naturaleza", se situaría, por principio, en una originaria antítesis frente a la categoría de pueblo, dado que, a diferencia de éste, antecedería a la oficialización de una sociedad política vertebrada en torno a un Estado centralizado. En oposición a Pueblo, forzado a converger en los moldes del paradigma clásico de lo político, en la unidad del Estado, en "El Uno", la multitud es irreductible a ello. Se resiste, precediéndola, a la representación, al pacto social moderno, siendo, a la postre, una multiplicidad inconmensurable (Negri, 2003, p. 106).

Así contemplado, se querrá colegir que el poder inscrito en la multitud sería el consistente en poner al desnudo una venganza de la persistente in-determinación de pueblo, del sobreviviente peso impolítico suyo, ante su acartonamiento en la moldura de la determinación moderna de Pueblo. Como tal, la esencia de la multitud es, pues, radicalmente reactiva a la modernidad. En sí misma, anhela cortocircuitar los $I S$ instituidos de pueblo acordes al diseño programático del Estado-nación. Con la resignificación de la multitud se pretende redirigir y rentabilizar, en términos de practicidad política, la ostensible dislocación estructural resultante de una fehaciente des-identificación de la masa en el espejo de las variedades del $I S$ de pueblo canonizadas a raíz de la modernidad.

\section{3. El populismo: la construcción de pueblo en ruptura con el pacto social}

Del populismo puede afirmarse lo que Aristóteles atribuyera al vocablo Ser en su Metafísica: que se dice de múltiples modos y que, por tanto, difícilmente toparemos una explicitación unívoca. Podríamos incluso vislumbrar, tantas enunciaciones, como autores han abordado su examen. Empero, bajo el imperativo de una precisión conceptual, arrojemos una provisional definición aproximativa útil por tratar de compendiar el denominador común a todas ellas: la construcción prospectiva de una unitaria y distintiva comunidad en donde, en un tal cometido, se realza un elemento de timbre emocional. Aun así, sería un gesto de ingenuidad la admisión de que el populismo se desprende en exclusiva de un clima circunstancial de pronto acaecido en la trama de las sociedades de la modernidad avanzada. Acaso más certero sería partir del presupuesto en donde al populismo se le hace indisoluble de la misma esencia de lo político, por mucho que, en efecto, ciertas determinaciones históricas faciliten su implantación y espoleo. ${ }^{21}$

\footnotetext{
${ }^{21} \mathrm{Al}$ hilo de la anterior inquisición pudiéramos retrotraernos a las enseñanzas encerradas en los Discursos sobre la Primera década de Tito Livio de Maquiavelo o en el Leviathan de Hobbes, en donde se resalta la esterilidad de un poder político que osara obrar de espaldas al concurso de un entrecruzado haz de afectos circulantes por el entramado social. Se ha llegado a aducir que la íntima naturaleza de lo político consiste precisamente en una eficaz gestión de las pasiones, que uno de los estructurantes esenciales en el guión interno suyo es un juego administrador de los antes mencionados afectos colectivos (Ansart, 1983). Un aspecto, por lo demás, pobremente evaluado en manos de una perspectiva teórica de corte sesgadamente racionalista. Un juego basado en una estrategia con vista a la conquista y manejo de una circunstancial exaltación o contención de estos afectos. Un juego en donde, inspirándose en tal cometido estratégico, se ha empleado corrientemente una teatralizada dramaturgia. En ella se pone en liza una efectista imaginería con la que se espolearía un tipo de praxis colectiva inducida de la apelación a un recurso representacional de orden mítico e imaginario (Balandier, 1994, p. 15-44).
} 
No cabe duda de que un contexto coyuntural contaminado por la percepción de un declive del crédito institucional favorecerá un rebrote populista, facilitando una tentativa de fagocitosis de lo político por parte de éste. Un ensimismamiento tal excitaría en la masa la adopción de una expresividad reactiva al andamiaje preceptivo sostenido desde la política moderna y su correlato, como determinación, en la categoría de pueblo. En este aspecto, el populismo encuentra su arraigo y fuente de hechizo en la apreciación, más artificiosa que real, de unas demandas generalizadamente irreconocidas e insatisfechas en la inacción gubernamental, debido a la acusación de un congénito déficit sistémico contraído por la representación política heredada de la modernidad y reproducido en el arco asociado a la participación en sus instituciones. El populismo comparece como un discurso detonante de una ola ideológica que, travestida de una redentora aura de autenticidad moral, promueve una borrosa contraoferta al ideal político labrado sobre un consenso fraguado en una transparencia deliberativa mediadora entre los copartícipes del espacio público, fórmula paradigmática esencialmente adoptada en el ideario de las democracias liberales contemporáneas. Para ello, su discursividad apela a un pathos que, incorporado por la masa como catalizador de una reivindicada unidad colectiva, se orienta a violentar los pilares del pacto social moderno; y en el seno de esta etérea unidad suya se presumiría tanto acoger como resolver unas demandas sociales sistemáticamente incumplidas por parte de las élites políticas.

Es difícil apreciar la fertilidad de una lectura rezumante de un disenso instituyente atesorado en el populismo que no se agote en el simple efectismo. Este se postularía como una discursividad política performativa emplazada a la interpelación de una entidad de pueblo como recurso inspirador para un reordenamiento de la organización social, a fin de responder a las desatendidas reivindicaciones de los grupos dominados, de la Plebs. Supuestamente, demandas que, de otro modo y teniendo en cuenta la falsedad insita al modelo de representación moderno, no podrán ser explicitadas, incorporadas y encarriladas por los actores sociales en el cauce de un orden gubernamental vigente. Esta sería la tesis que subscribiría, por ejemplo, Laclau: la unidad de pueblo visto como un "significante vacío" que consigue llenar y articular, jugando con la adición del afecto, la heterogeneidad de un muy diverso reclamo colectivo, generando una cadena de equivalencias con la totalidad de lo social (Laclau, 2005, p. 282-283). Por tanto, el pronunciamiento clásico en donde se resumiría la preconcebida virtud de la lógica populista sería aquel en el cual se remarcaría su acicate para desenmascarar «la universalidad de lo parcial y la parcialidad de lo universal» (Laclau, 2005, p. 278). Acaso más sugerente fuese otra opción hermenéutica: atender al análisis interpretativo del populismo de acuerdo con su condición de síntoma revelador de un daño en los adentros del tejido comunitario a consecuencia del imperialismo de la lógica económica. A tenor de ello, entenderlo como una ineficaz réplica sanadora de este daño por vía de una apelación a los afectos colectivos, sacando partido de una adhesión emocional en torno al pueblo canalizada en términos contrainstitucionales que, aprovechándose del poso de descrédito de la razón ilustrada, impugna que la base de asiento del orden social sea el tipo de racionalidad política canonizada en la modernidad (Villacañas, 2015, p. 15-16). 
De esta guisa, la inquietante indefinición y homogeneidad en su recurrencia al pueblo, en tanto inexcusable requisito para la imantación de la masa en una praxis transgresora de la racionalidad involucrada en el pacto social, convierte al populismo en una retórica sumamente ambigua: en una predisposición para su concreción en fines políticos con un signo de lo más aleatorio y ambivalente.

\section{A modo de conclusión}

Fieles al dictado teórico auspiciado desde la historia conceptual hemos explorado cómo el IS ha desempeñado un papel fundamental en la génesis y desarrollo de las diversas categorizaciones discursivas de pueblo en el transcurso evolutivo de la modernidad. De manera que sugerimos que a la revelación del desgaste de los $I S$ modernos de pueblo le sucede el brote de una magmática in-determinación pre-política - ¿y post-política?- de pueblo cincelada en formas reactivas a las instituidas en la época moderna. A colación de ello recurrimos al término metafórico masa, con el cual nombrar el denominador común a unas inclinaciones sociopolíticas actualmente tendentes a una des-identificación con respecto a las fórmulas de definición modernas de pueblo, escrutando el alcance sociológico de tres de sus proyecciones paradigmáticas: micro-identidades, multitud y populismo. 


\section{Bibliografía}

Adorno, Th. (1992). Dialéctica negativa. Madrid: Taurus.

Agamben, G. (1998). Homo sacer. El poder soberano y la nuda vida. Valencia: Pre-Textos.

Agamben, G. (2012). Teología y lenguaje: del poder de Dios al juego de los niños. Buenos Aires: Las Cuarenta.

Anderson, B. (1993). Comunidades imaginadas. Reflexiones sobre el origen y la difusión del nacionalismo. Ciudad de México: FCE.

Anderson, P. (1992). El Estado Absolutista. Madrid: Siglo XXI.

Ansart, P. (1983). La gestion des passions politiques. Lausana: L'Age d'Homme.

Arendt, H. (1988). Sobre la revolución. Madrid: Editorial Alianza.

Baczko, B. (2005). Los imaginarios sociales. Memorias y esperanzas colectivas. Buenos Aires: Nueva Visión.

Bajtín, M. (1990). La cultura popular en la Edad Media y el Renacimiento. Madrid: Editorial Alianza.

Balandier, G. (1994). El poder en escenas. De la representación del poder al poder de la representación. Buenos Aires: Paidós.

Baudrillard, J. (1993). A la sombra de las mayorías silenciosas. Cultura y Simulacro. Barcelona: Kairós.

Baudrillard, J. (1996). El espejo de la producción. Barcelona: Gedisa.

Bergua, J. A. (2007). «La gente», Intersticios. Madrid: Revista Sociológica de Pensamiento Crítico, 1(1), 17-36.

Bergua, J. A. (2015). Postpolítica. Elogio del gentío. Madrid: Biblioteca Nueva.

Beriain, J. (1996). La integración en las sociedades modernas. Barcelona: Anthropos

Beriain, J. (2000). La lucha de los dioses en la modernidad. Barcelona: Anthropos

Bueno, G. (1997). La democracia como ideología. Madrid: Abaco, 12(13), 11-34.

Bueno, G. (2008). La vuelta del revés de Marx (consideraciones a propósito de la edición en PDF del Primer ensayo sobre las categorías de las ciencias políticas, Logroño 1991). Madrid: Catoblepas, Revista Crítica del Presente, 76(2).

Bueno, G. (2017). Principios filosóficos del marxismo (transcripción de una conferencia pronunciada en el año 1983, coincidiendo con el centenario de la muerte de Marx, en la Facultad de Filosofía y Letras de la Universidad de Oviedo). Oviedo: El Basilisco, Revista de Materialismo Filosófico, 49, 99-109.

Burke, E. (2003). Reflexiones sobre la Revolución en Francia. Madrid: Editorial Alianza.

Burke, P. (1991). La cultura popular en la época moderna. Madrid: Editorial Alianza. 
Carretero, E. (2018). El laberinto de la socialidad: utopía y distopía. Barcelona: Anthropos, 248, 5-26.

Castoriadis, C. (1983-1989). La institución imaginaria de la sociedad. Madrid: Tusquets, 2 vols.

Castoriadis, C. (1994). Lo imaginario: la creación en el dominio historicosocial. Los dominios del hombre. Barcelona: Gedisa, 64-77.

Castoriadis, C. (1998). La democracia como procedimiento y como régimen. En: El ascenso de la insignificancia. Madrid: Editorial Alianza., 218-238.

Castro Nogueira, L. A. (1997). La risa del espacio. El imaginario espacio-temporal. En: La cultura contemporánea: una reflexión sociológica. Madrid: Tecnos.

Cortés, H. (1996). Claves para una lectura de Hiperión. Filosofía, política, ética y estética en Hölderlin. Hiperión.

Crossman, R. H. S. (2003). Biografía del Estado Moderno. Ciudad de México: FCE.

Deleuze, G. y Guattari, F. (1994). Mil Mesetas. Capitalismo y esquizofrenia. Valencia: PreTextos.

Duby, G. (1980). Los tres órdenes o lo imaginario del feudalismo. Madrid: Taurus.

Dumont, L. (1987). Ensayos sobre el individualismo. Madrid: Editorial Alianza.

Elias, N., (1989). El proceso de civilización. Investigaciones sociogenéticas y psicogenéticas. Ciudad de México: FCE.

Fichte, J. G. (1994). Discursos a la nación alemana. Madrid: Atalaya.

Foucault, M. (1967). Historia de la locura en la época clásica. Ciudad de México: FCE.

Foucault, M. (1994). Vigilar y castigar. Madrid: Siglo XXI.

Foucault, M. (1997). Las palabras y las cosas: Una arqueología de las ciencias humanas. Madrid: Siglo XXI.

Gauchet, M. (1998). La religión dans la démocratie. Parcours de la laïcité. París: Gallimard.

Gellner, E. (2001). Naciones y nacionalismo. Madrid: Editorial Alianza.

Ginzburg, C. (1999). El queso y los gusanos. El cosmos según un molinero del siglo XVI. Muchnik. Ciudad de México: Atajos.

Gramsci. A. (1980). Notas sobre Maquiavelo. Buenos Aires: Nueva Visión.

Gurièvitch, A. (1990). Las categorías de la cultura medieval. Madrid: Taurus.

Habermas, J. (1981). ¿Pueden las sociedades complejas desarrollar una identidad racional?. En: La reconstrucción del materialismo histórico. Madrid: Taurus, 85-114.

Hazard, P. (1998). El pensamiento europeo en el siglo XVIII. Madrid: Editorial Alianza.

Hegel, G. W. F. (1968). Filosofía del derecho. Buenos Aires: Claridad.

Hegel, G. W. F. (1975). Aesthetics trans. T. M. Knox. Oxford: Oxford University Press. 
Hegel, G. W. F. (1981). Fenomenología del espíritu. Ciudad de México: FCE.

Heidegger, M. (1996). Caminos del bosque. Madrid: Editorial Alianza.

Heidegger, M. (2000). El ser y el tiempo. Ciudad de México: FCE.

Herder, J. G. (2007). Filosofía de la historia para la educación de la humanidad. Madrid: Espuela de Plata.

Huizinga, J. (2001). El otoño de la Edad Media. Madrid: Editorial Alianza.

Hobsbawn, E. (1991). Naciones y nacionalismo desde 1870. Madrid: Crítica.

Innerarity, D. (1993). Hegel y el romanticismo. Madrid: Tecnos.

Joas, H. (2017). ¿El incremento de opciones como peligro?. En: Sánchez Capdequí, C. (Ed.) (2017). La creatividad social: narrativas de un concepto actual. Madrid: CIS, 249-262.

Koselleck, R. (1993). Historia conceptual e historia social. En: Para una semántica de los tiempos históricos. Buenos Aires: Paidós, 106-127.

Koselleck, R. (2003). Aceleración, prognosis y secularización. Valencia: Pre-Textos.

Laclau, E. (2005). La razón populista. Ciudad de México: FCE.

Le Goff, J. (1999). La civilización del occidente medieval. Buenos Aires: Paidós.

Lenin, V. I. (1997). El Estado y la Revolución. Madrid: Fundación Federico Engels.

Lenin, V. I. (2010). ¿Qué hacer?. Claves para el Socialismo.

Lübbe, H. (1983). Estado y Religión civil. Un aspecto de la legitimidad política. En: Filosofía práctica y Teoría de la historia. Montevideo: Alfa, 79-107.

Luhmann, N. (1998). Sistemas sociales. Lineamientos para una teoría general. Barcelona: Anthropos.

Lukács, G. (1969). Thomas Mann. Barcelona: Grijalbo.

Lukács, G. (1975). Historia y consciencia de clase. Barcelona: Grijalbo.

Maffesoli, M. (1990). El tiempo de las tribus. El declive del individualismo en las sociedades de masa. Madrid: Icaria.

Maffesoli, M. (2005). La transfiguración de lo político. La tribalización del mundo posmoderno. Barcelona: Herder.

Martínez Marzoa, F. (1976). De la revolución. Madrid: Alberto Corazón.

Martínez Marzoa, F. (1983). La filosofía de "El capital”. Madrid: Taurus.

Martínez Marzoa, F. (2018). El concepto de lo civil. Madrid: La Oficina de Arte y Ediciones.

Marx, K. (2010). Introducción para la Crítica de la filosofía del derecho de Hegel. Biblioteca Nueva.

Marx, K. (2000). Crítica del programa de Gotha. www.elaleph.com.

Marx, K. (1970). La guerra civil en Francia. Ricardo Aguilera. 
Marx, K. (1975). El dieciocho brumario de Luis Bonaparte. Madrid: Akal.

Marx, K. \& Engels, F. (1974). La ideología alemana. Barcelona: Grijalbo.

Marx, K. \& Engels, F. (2013). Manifiesto del partido comunista. Madrid: Fundación de Investigaciones Marxistas.

Negri, T. (2003). Del retorno: abecedario biopolítico. Madrid: Debate.

Negri, T. (2004). Cinco lecciones en torno al imperio. Buenos Aires: Paidós.

Negri, T. y Hardt, M. (2005). Imperio. Buenos Aires: Paidós.

Nietzsche, F. (1994). Sobre verdad y mentira en sentido extramoral. Madrid: Tecnos.

Ovejero, F. (2018). La deriva reaccionaria de la izquierda. Barcelona: Página Indómita.

Roca Barea, M. E. (2016). Imperiofobia y leyenda negra. Madrid: Siruela.

Rousseau, J. J. (1988). El Contrato social. Madrid: Atalaya.

Sartori, G. (2007). ¿Qué es la democracia?. Madrid: Taurus.

Schmitt, C. (2009). Teología política. Madrid: Trotta.

Schumpeter, J. (1983). Capitalismo, socialismo y democracia. Turlock: Orbis.

Sièyes, E. J. (2003). ¿Qué es el Tercer Estado?. Madrid: Editorial Alianza.

Sloterdijk, P. (2002). El desprecio de las masas. Ensayo sobre las luchas culturales de la sociedad moderna. Valencia: Pre-Textos.

Sloterdijk, P. (2009). Esferas III. Madrid: Siruela.

Starobinki, J. (1988). 1789, los emblemas de la razón. Madrid: Taurus.

Storey, J. (2002). Teoría cultural y cultura popular. Madrid: Ediciones Universitarias.

Taylor, Ch. (2018). Historia, crítica, cambio social y democracia. Entrevista con Charles Taylor por Ulf Bohmann y Darío Montero. En: Basaure, M. \& Montero D. (Comps.). Barcelona: Anthropos, 95-117.

Tocqueville, A. (2006). La democracia en América. Madrid: Editorial Alianza.

Villacañas, J. L. (2015). Populismo. Madrid: La Huerta Grande.

Virno, P. (2003). Gramática de la multitud. Para un análisis de las formas de vida contemporáneas. Madrid: Traficantes de sueños.

Voegelin, E. (2006). Nueva ciencia de la política. Madrid: Katz. 